\title{
РЕЦЕНЗИЯ НА КНИГУ \\ ИСЛАМА ЗАРИПОВА \\ И МАРАТА САФАРОВА \\ «АХМЕТЗЯН МУСТАФИН: \\ ИЗ ИСТОРИИ ИСЛАМА В СССР»
}

Дмитрий Опарин

dimaoparin@hotmail.com

DOI: http://dx.doi.org/10.24848/islmlg.08.1.06

\section{Dmitry Oparin}

Ph.D. in History, Senior Lecturer of the History Department of Moscow State University, Research Fellow at the Institute of Social Policy, Higher School of Economics.

Review of the book "Abmetzyan Mustafin: From the History of Islam in the USSR" by Islam Zaripov and Marat Safarov.

$\mathrm{M}$ онография Ислама Зарипова и Марата Сафарова - результат долгого и скрупумезного историко-антропологического исследования, посвященного не столько биографии имама Московской соборной мечети Ахметзяна Мустафина (19021986), сколько повседневности ислама в СССР, в первую очередь в московском регионе и советской государственной политике в сфере мусульманского культа. Авторы пишут во введении: «Цель данной работы - максимально полно рассмотреть жизнь имама в контексте эволюџии государственно-религиозных отношений в СССР. В исследовании особое внимание удемяется механизму существования ислама в СССР».

ГАавы книги выстроены по хронологии. Через призму судьбы

\section{Дмитрий Опарин}

K.u.H., стариий nреподаватель исторического факультета МГУ им. М.В. Аомоносова, научньии сотрудник Института сочиальной политики НИУ ВШЭ Мустафина авторы рассматривают важнейшие явления татарской религиозной жизни всего XX века - Ажадидизм, мировосприятие татарской интемлигенции предреволюџионного периода, реАигиозную традицию и ее трансляџию на протяжении столетия, колмективизацию в татарской деревне и интенсификацию миграционных проџессов, репрессии против национальной интелмигенџии и акторов религиозной сферы, динамику государственного нажима на ислам в СССР, послевоенную повседневную жизнь татарской общины Москвы и Подмосковья, роль мусульманских религиозных мидеров в контексте советской внешней политики. Безусловно, каждая из вышеперечисленных проблематик настолько широка и многогранна, что заслуживает отдельного исследования, вернее непрекращающейся серии исследований. Авторы в историографическом очерке упоминают работу С.Н. Абашина (2015). Марат Сафаров и Ислам Зарипов отмечают методологию историко-антропологического исследования Сергея Абашина, заключающуюся в рассмотрении экономического, политического и социального развития Средней Азии через призму одного села с помощью микроисторического и мокального антропологического подходов - от частного к общему. Также и в Аанном случае через непростую судьбу одного имама раскрывается весь плюрализм татарской 
культуры (в самом широком понимании этого слова) на протяжении всего XX века. Американский антрополог КмиффорА Гирц, заложивший основы не только интерпретативного поворота в антропологии, но и начертивший векторы развития науки в последней четверти XX века, писал в своей книге «Интерпретация культур»: «Это значит мишь то, что антрополог, как правило, выходит к более широким интерпретациям и к более абстрактному уровню анализа через этап подробного изучения чрезвычайно мелких явлений» (Гирџ, 2004, с. 29). КАючевым принџипом «насышенного описания» Гирџа явмяется контекстуацьность - ученый должен поставить объект своего исследования в контекст, только внутри которого «поведения индивидов, институты или проџессы» «могут быть адекватно, т.е. "насыщено”, описаны» (Гирџ, 2004, с. 21). Авторам удалось контекстуализировать биографию Ахметзяна Мустафина, проблематизировать и концептуализировать досконально исследованные ими факты жизни московского имама. Это первая причина, по которой работу можно назвать не просто источниковедческой, а историко-антропологической.

Вторая - удачный синтез архивного исследования с антропологическим. Авторы монографии вводят в научный оборот 19 архивных дел из Центрального архива города Москвы (ЦАГМ), отдельные советские документы публикуются ими в приложении. Вероятно, Аля последующих пубцикаций следует внимательно проработать фонды Государственного архива Российской Федераџии (ГАРФ). Тем не менее, публикаџию ранее не опубликованных архивных документов по истории этнической Москвы, в частности истории ислама в советский период, трудно переоценить. Это одна из важнейших составцяющих цюбого исторического исследования. Источниковедческую работу Марата Сафарова и Ислама Зарипова, на мой взгляА, можно сравнить разве что с одним из кучших исследований по истории этнической Москвы - трудом Е.Н. УАиџкого «История Московской еврейской общины. Аокументы и материалы» (2006). Полноправным источником наряду с архивными документами оказываются полевые материалы. Авторы перечисляют восемь глубоких интервью с московскими татарами, заставшими Ахметзяна Мустафина. Некоторые из респондентов могли поделиться своими воспоминаниями даже о 1920-х годах. Несмотря на то, что авторы перечислици в приложении только восемь информантов, всем специалистам по истории и современности мусульман Москвы известно, что Марат Сафаров и Исмам Зарипов успели пообщаться и продолжают вести свои исследования среди намного большего числа пожилых московских татар. Эта масштабная и многолетняя работа отразияась и в тексте монографии. В истории антропологии есть такое понятие, как salvage ethnography (спасательная этнография) - наџеленность исследователя записать исчезающие обряды или забываемый фольклор. Авторы сохраняют устную память о московских мусульманских практиках, событиях, явлениях и мокаџиях XX века. Они понимают, что важно прямо сейчас зафиксировать воспоминания очевидџев тех лет, разобрать семейные архивы. Тем не менее, расшифровка интервью в научной пубцикации, - а эта книга явцяется, безусловно, академическим трудом, - требует особенной осторожности - авторы не оговорици степень редакторской правки интервью. А она, без сомнения, видна. Я считаю, что расшифровка должна быть дословной, а исключение каких- ибо частей диалога нужно отмечать. Если же интервью было взято на татарском языке (или на смешении двух языков), то я советовац бы давать расшифровку на татарском и русском языках и, вероятно, даже ввести такое понятие, как «татарский московский устный нарратив».

Следует отметить, что авторы проделали очень важную работу по анализу источников, а также написали достаточно полный историографический очерк, собрав все основные работы по истории мусульманских практик советских татар. Большая часть фото- 
графий опубликована в книге впервые. ОАнако практически нигде не указан источник снимков. Снимки повседневной московской татарской жизни можно найти не только в семейных собраниях, но и в архивах Музея архитектуры имени А.В. Щусева, Музея современной истории России, Џентральном государственном архиве города Москвы, Российском государственном архиве кинофотодокументов. Часть снимков взята из послеАнего архива, однако остальные фотографии, к сожалению, опубцикованы без атрибуции, хотя авторы, скорее всего, работали во всех вышеуказанных архивах.

Я хотел бы отметить отдельные идеи авторов, артикулированные и аргументированные в книге. Во-первых, Ислам Зарипов и Марат Сафаров отмечают ошибочность мапидарного деления исламских практик в СССР на офиџиальные и неофиџиальные. Они показывают на примере профессионального пути Ахметзяна Мустафина и характера его взаимоотношения с верующими, что «официальный» и «неофициальный» ислам - понятия, упрощающие реалии того времени. Некоторые из будущих имамов Соборной мечети или сотрудников Ааниловского мусульманского кладбища посещали до своего назначения московские меджиисы на квартирах, да и после занятия «религиозного поста» совмещами «официальные» и «неофиџиальные» практики, грань между которыми в том советском контексте была условной. Авторы затрагивают важнейшие вопросы московской советской татарской жизни - особенная роль мусульманских кладбиш Москвы и области, рост вцияния женщин в ритуальном пространстве, в сфере трансляции религиозных практик и рецигиозного мировоззрения. Аанное исследование открывает новые грани не только истории ислама в СССР и истории татарского населения страны, но и истории Москвы. Авторы подробно рассказывают о мокациях исхода московских и подмосковных татар - из каких регионов прибывали татары в советский период, как они взаимодействовали с частично сохранившейся в жернове войн и репрессий касимовской интемлектуальной элитой. Впервые в историографии появцяется такое подробное описание татарской советской повседневной жизни двух ключевых Амя этой общины районов Москвы - Мещанского и Замоскворечья. Отдельно я хотец бы отметить статью М.А. Сафарова «Повседневная жизнь московских мусульман в 1960-1980-х годах» (2012). И, наконец, авторы проблематизируют роль самого имама в контексте антирелигиозной пропаганды, цомки традиционных механизмов трансляции не только сакрального знания, но и культурно-национального: «В условиях отсутствия религиозных изданий и периодики, при невозможности чтения многими татарами молодого и среднего возраста дореволюционных исламских книг, напечатанных с помощью арабской графики, проповеди Ахметзяна Мустафина явцялись по существу единственной возможностью услышать и узнать о сути своей религии. Аیя многих мусульман проповеди Мустафина стали важными шагами в становмении собственного мировоззрения» (Зарипов, Сафаров, 2017, с. 138).

ОАним из подвигов Ахметзяна Мустафина было спасение здания Московской соборной мечети в конце 1970-х годов. При подготовке к Олимпийским играм 1980 года и проектировании спортивного комплекса «ОАимпийский» наА мечетью, построенной в 1904 году и не закрывавшейся на протяжении всего советского времени, нависла угроза. Умело используя свой авторитет, а также заинтересованность советской вцасти в выстраивании отношений с мусульманскими странами, Ахметзян Мустафин сумел отстоять старое зАание, имевшее огромное культурного значение не только Аця московских татар, но и для историкоархитектурного наследия города. В 2011 году историческое здание мечети в Выползовом переулке было снесено. К сожалению, тогда в Москве не оказалось имама, обладавшего тем же авторитетом и той же силой духа, какими был известен Ахметзян Мустафин. 


\section{БИБЛИОГРАФИЯ}

Абашин, С.Н. (2015). Советский кишлак: между колониализмом и модернизацией. Москва: Н $\Lambda$ О.

Гирџ, К. (2004). Интерпретаџия культур. Москва: РОССПЭН.

Зарипов, И.А., Сафаров, М.А. (2017). Ахметзян Мустафин: из истории ислама в СССР. Москва: ИА «Медина».

Сафаров, М.А. (2012). Повседневная жизнь московских мусульман в 1960-1980-х гоАах // Неприкосновенный запас. № 4 (84). С. 139-148.

Умицкий, Е.Н. (2006). История Московской еврейской общины. Аокументы и материалы. Москва: КОРА ОАимп. 